\title{
Health Care and the 2020 Us Election
}

\author{
Mildred A Schwartz* \\ University of Illinois at Chicago, USA \\ *Corresponding author: Mildred A Schwartz, University of Illinois at Chicago, USA. \\ To Cite This Article: Mildred A Schwartz. Health Care and the 2020 Us Election. Am J Biomed Sci \& Res. 2019 - 4(3). AJBSR.MS.ID.000784. \\ DOI: 10.34297/AJBSR.2019.04.000784
}

Received: : July 22, 2019 | Published: July 26, 2019

\section{Opinion}

Health care promises to be a leading issue in the 2020 US election. In the past, health care policies helped Democrats get elected. Currently, new policies may not give the Democrats such a clear advantage because of divisions in the party associated with contenders for the presidential nomination. Health care promises to be a critical issue in the forthcoming US election, ranking among the most contentious issues roiling the public sphere and accentuating the division between Republicans and Democrats [1]. To a large extent, health care played a similar role in the 2018 midterm election $[2,3]$.

According to Gallup's Midterm Election Benchmark poll, 80 percent of registered voters interviewed less than a month before that election chose health care as the most important issue affecting their vote for Congress. Although its importance was greater by 15 percentage points among Democrats than Republicans, 72percent of the latter still chose health care as most important [4]. Voters, concerned by Republican promises to do away with the Affordable Care Act (Obamacare), chose Democratic candidates in sufficient numbers and in sufficient states to swing the House to a Democratic majority. Contributing to that outcome were Independents, many of whom had drifted away from previous support for the Democrats.

If in 2018, votes for the Democrats signaled support for Obamacare and fear that its benefits would disappear under Republican control, the coming election presents a more complex environment for contending parties and uncertain voters. The official Republican position remains opposed to Obamacare along with hints of some still undefined promise to replace it with a new policy [5]. But currently, it is the Democratic presidential hopefuls that now offer a range of alternatives contributing to a new uncertainty. The political environment today, compared to 2018, differs in multiple ways. Currently there is a sitting Republican President, still determined to do away with Obamacare. Although there is a majority Democratic House committed to, at the very least, the continuation of Obamacare if not its expansion, it lacks internal unity, with sharp divisions between progressives and moderates and between newcomers and an old guard. Finally, there is an unprecedented number of Democratic presidential candidates vying to move to the forefront by a convincing display of their potential to lead the party to victory.

Who will become the Democratic Party's official presidential candidate, which policy alternatives will become its official policy, and how both will affect voters are still unknown? But observers, both inside and outside the Democratic Party, currently see fissures they predict are likely to impact the election outcome [6-8]. With respect to health care, divisiveness emerges from the most expansive position: a government-run single-payer universal health system, also known as Medicare for all. Such a system would do away with private insurance and require new tax revenues.

During the two nights of the first debate, approval for that option, initially associated with Senator Bernie Sanders, was additionally embraced by Senators Elizabeth Warren and Kamala Harris (with the latter appearing to withdraw her vote after the debate), and Mayor Bill de Blasio. But concern about voter reaction to such changes has mobilized other presidential candidates to support a public option, allowing people to buy "Medicare-forall-who-want-it." Although there are variations among these two options, they do not alter the existence of a deep split within the party [6]. Issues other than health care divide Democrats and the electorate and how important those may become during the coming election still unknown. But even more troublesome for the Party's future success is evidence of basic differences among the presidential candidates, documented in the answers they gave to the New York Times (2019).

In general, answers differentiated among old-timers like Joe Biden, representing a more moderate stance, but also placed Bernie Sanders, another old-timer, in the most radical category. Whether the Democrats end up with more progressive or more centrist policies, they will antagonize some share of their natural supporters. But what could be even more destructive to their aspirations is how President Trump has already begun conducting his reelection campaign by arguing that even the smallest sign of progressivism demonstrates how deaf the Democrats are to concerns of the people. He is a formidable opponent, attuned to the 
value of personal diatribes in arousing voters, and it will take great skill to defeat him. Who the Democrats chose as their candidate, how they present policy options, and the extent of their eventual unity will all determine the outcome [9].

\section{References}

1. Krugman, Paul (2019) The New Plot Against Obamacare. The New York Times, USA.

2. Lowrey, Annie (2018) The One Issue That's Really Driving the Midterm Elections. The Atlantic, USA.

3. Blendon, Robert, Benson, John M, Mc Murtry, Caitlin L (2018) Health Care in the 2018 Election. New England Journal of Medicine, USA pp. 379-e32.
4. Newport, Frank (2018) Top Issues for Voters: Healthcare, Economy, Immigration. Gallup, USA.

5. Sanger Katz, Margot (2019) Dismantling Health Law Undermines New Policies. The New York Times, USA.

6. Goodnough, Abby, Kaplan, Thomas (2019) Democrat vs Democrat: How Health Care is Dividing the Party. The New York Times, USA.

7. Nwanevu, Osita (2019) The Democratic Divide on the Future of Health Care. The New Yorker, USA.

8. Wall Street Journal (2019) Democratic Debate Bares Divisions on Health Care, Unity Against Trump, USA.

9. (2019) 18 Questions, 21 Democrats. The New York Times, USA. 